\title{
SPATIAL-TEMPORAL DYNAMICS ANALYSIS OF COASTAL LANDSCAPE PATTERN ON DRIVING FORCE OF HUMAN ACTIVITIES: A CASE IN SOUTH YINGKOU, CHINA
}

\author{
CAO, K. ${ }^{1,2}-$ SUO, A. N. ${ }^{1,2^{*}}-$ SUN, Y. G. ${ }^{1,2}$ \\ ${ }^{I}$ National Marine Environment Monitoring Center, Dalian, China \\ (phone/fax:+086-0411-84783313) \\ ${ }^{2}$ Key Laboratory of Sea Area Management Technology, SOA, Dalian, China \\ (phonelfax:+086-0411-84783718) \\ *Corresponding author \\ e-mail:san720@sina.com \\ (Received $28^{\text {th }}$ Oct 2016; accepted $28^{\text {th }}$ Feb 2017)
}

\begin{abstract}
This paper chooses south Yingkou coast as study area, some landscape pattern indexes such as water landscape dominant index, wetland landscape index, building disturb index and landscape stability degree are created to describe coastal landscape pattern change. Remote sensing images obtained in 1990,2000,2005,2010 and 2015 were employed as data sources. The result shows that water landscape which include salt pools, fishing ponds and tidal channel decreased, while terrain landscape include building land and grassland increased. Sea reclamation by human activities weakened coastal landscape characteristics in different sub-regions. The north sub-region has changed from salt pools, fishing ponds to town and industry landscape, the water landscape dominant index reduces to 0.15 and building disturb index raises to 45.40. The middle sub-region is just changing from water landscape to terrain landscape. Its water landscape dominant index is 0.56 and building disturb index is 10.30 . The south sub-region still maintains water landscape. Its water landscape dominant index is 0.85 and building disturb index is only 4.40. The landscape stability degree of Iand II covered most areas.Idegree areas account for $35.73 \%$. IIdegree areas account for $39.86 \%$, while the areas which landscape types changed above 2 times, only account for $24.41 \%$.
\end{abstract}

Keywords: coastal zone; landscape pattern change; sea reclamation, remote sensing images, south Yingkou coast

\section{Introduction}

Coastal zone is a unique ecological transition zone formed under the mutual effect of sea and land (Sunamura, 1992; Yang, 2003). With complex ecosystem structure and diverse functions, it can be influenced by ocean tides, waves and other hydrodynamic environments, also by topography, landform and other terrestrial environment, besides, coastal zone plays an extremely important role in disaster prevention and mitigation, climate regulation, maintenance of biological diversity and regional ecological security, it is also an important ecological safeguard of sustainable economic and social development for coastal regions (Carter, 1988; Gao et al., 2014; Xu et al., 2014). In recent years, on driving of China's rapid coastal economic development, land reclamation, aquaculture 
around the sea, port construction and other human exploitation activities, varying degrees of fragmentation of coastal zone landscape pattern have been raised, the integrity of coastal zone ecosystem if facing a serious threat (Liu et al., 2009; Wan et al., 2009; Suo and Zhang, 2015). Landscape scale is the optimum scale for studying the affect of large-scale human exploitation on spatial pattern of coastal zone (Suo et al., 2009), through the analysis of wetland landscape pattern changes in coastal zone during human exploitation, the changing direction and strength of wetland landscape pattern in coastal zone by human activities can therefore be revealed, thus providing scientific evidence for optimizing the development of coastal zone spatial layout and protecting natural coastal wetlands.

Landscape pattern is the concrete manifestation of landscape heterogeneity, the purpose of landscape pattern analysis aims to reveal the meaningful order or rules hidden in the seemingly chaotic landscape patterns (Forman, 1986; Xiao et al., 2003). At present, domestic and international studies on landscape pattern in coastal zone mainly focus on natural landscape pattern and its change process of coastal zones, study range mainly covers the Liaohe River Delta, Yellow River Delta, Yangtze River Delta, Pearl River Delta and North Jiangsu coastal tidal zone (Chen and Fu,1996; Wang et al., 1997; Zeng et al., 1999; Ye et al., 2005; Zuo et al., 2012), and studies focusing on the changing process of landscape pattern in coastal zone under concentrated human development are relatively rare, the only studies mainly focus on analyzing the overall changing process of sea reclamation on regional landscape patterns (Sun et al., 2010, 2011). However, spatio-temporal dynamics analysis of coastal water landscape pattern on driving of large-scale human exploitation are rarely reported, especially studies against landscape pattern changes in reclamation areas of coastal zone, and this direction is a basic approach to reveal the orientation and extent of large-scale human exploitation activities' change of landscape pattern in coastal zones.

This paper chooses the coastal zone at south Yingkou as the study area, an in-depth and systematic study of the changing process from the coastal zone wetland at south Yingkou being converted from salt pools landscape to salt pool-sea reclamation farming complex landscape, and finally into the landscape patterns of industry and town-salt pool-sea reclamation farming complex landscape, the changing process of landscape patterns on driving of large-scale human exploitation is carried out by using remote sensing and GIS technology as well as landscape ecology research methods, analyzing the change rules of coastal zone landscape patterns on driving of large-scale human exploitation, thus providing a theoretical basis and decision-making reference for intensive use of Yingkou coastal zone.

\section{Study area}

Located at the top of Liaodong Bay, south of the Liaohe River estuary, China, and between Bohai Avenue in Yingkou downtown and bedrock coastal zone of Tuan Mountain in Gaizhou, south Yingkou coast $\left(122^{\circ} 5^{\prime}-122^{\circ} 25^{\prime}, 40^{\circ} 25^{\prime}-40^{\circ} 40^{\prime}\right)$ covers a total area of $300 \mathrm{~km}^{2}$. The region was originally a flat and open muddy wetland in Liaodong 
Bay, the muddy wetland was built to a salt pool for the development of sea salt production industry through sea reclamation under the enthusiasm of national sea-reclaiming baysalt in the 1950's. Sea salt industry developed slowly at the end of last century, coastal salt pools and beaches with unobstructed water exchange are divided and transformed into fish, shrimp and other aquatic fishing ponds, forming a salt pool-fishing pond complex landscape pattern. Since the new century, with the proposal and implementation of Liaoning coastal economic zone development strategy, large areas of low-yielding salt pools are backfilled to provide expanding space for the space expansion and coastal industrial base construction of Yingkou city, coastal zone landscapes are transformed into an industry and town-salt pool-sea reclamation farming complex landscape pattern. According to the changing characteristics of landscape patterns in the study areas, this paper divides the study areas into northern sub-region, middle sub-region and south sub-region taking the boundary of Erdaogou and sea water intake and outlet, refer to the location and spatial division of study areas in Figure 1.

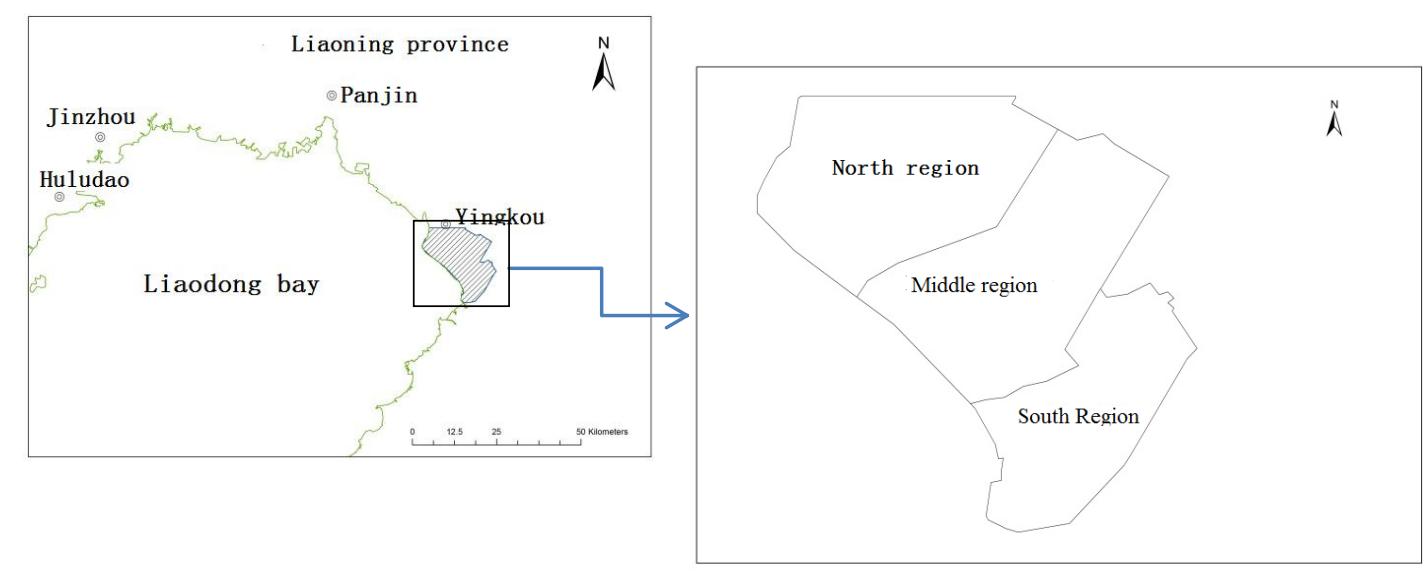

Figure 1. Location of study areas

\section{Data source and methods}

\section{Data source}

This paper collects 5 phases of satellite remote sensing images which can completely cover study areas and also with preferable image quality, refer to the data source of satellite remote sensing images in Table 1.

Table 1. Parametric of satellite remote sensing images in the study

\begin{tabular}{clllc}
\hline S/N & Data source & Track No. & Acquisition time & Spatial resolution (m) \\
\hline 1 & Landsat TM & $51 / 40$ & August, 1990 & 28.50 \\
2 & Landsat ETM & $120 / 32$ & July, 2000 & 28.50 \\
3 & Spot5 & $292 / 268$ & August, 2005 & 2.50 \\
4 & Spot5 & $292 / 268$ & September, 2010 & 2.50 \\
5 & GF-1 & 2108 & June, 2015 & 2.0 \\
\hline
\end{tabular}


Table 2. Coastal landscape types describe and image characteristics

\begin{tabular}{|c|c|c|c|}
\hline $\mathbf{S} / \mathbf{N}$ & $\begin{array}{l}\text { Landscape } \\
\text { types }\end{array}$ & Type description & Image characteristics \\
\hline 01 & Salt pool & Cofferdam pond used for mudflat sea salt production & $\begin{array}{l}\text { A rectangular pond area with sizes under sequential and ordered } \\
\text { arrangement. }\end{array}$ \\
\hline 02 & Fishing pond & Cofferdam pond used for mudflat aquaculture & $\begin{array}{l}\text { A rectangular pond area with similar shapes under parallel } \\
\text { arrangement. }\end{array}$ \\
\hline 03 & Cofferdam dam & $\begin{array}{l}\text { Earth-rock dam used for dividing to form fishing ponds and } \\
\text { salt pools. }\end{array}$ & A striped area with grid-like partition of impoundment water fields. \\
\hline 04 & $\begin{array}{l}\text { Water intake } \\
\text { and outlet }\end{array}$ & $\begin{array}{l}\text { Used for water field channels and flood discharge and } \\
\text { runoff channels for sea fishing ponds, drawing water by salt } \\
\text { pools and waste water discharge. }\end{array}$ & $\begin{array}{l}\text { A striped water field space that is distributed in the mosaics of salt } \\
\text { pools and fishing ponds, and is connected to sea area. }\end{array}$ \\
\hline 05 & Wetland & $\begin{array}{l}\text { Low-lying beaches under long-term ponding or } \\
\text { semi-ponding state. }\end{array}$ & $\begin{array}{l}\text { A low-lying land and waste impoundment area in gray brown or } \\
\text { green color. }\end{array}$ \\
\hline 06 & Lake & $\begin{array}{l}\text { Natural or artificial low-lying land with relatively closed } \\
\text { earth surface and impounding. }\end{array}$ & $\begin{array}{l}\text { A water field that is distributed separately with relative distribution } \\
\text { rules or natural boundary. }\end{array}$ \\
\hline 07 & Grassland & $\begin{array}{l}\text { Areas covered with natural and artificial herbaceous } \\
\text { vegetation. }\end{array}$ & A regular or irregular pale green land patch area. \\
\hline 08 & Building land & $\begin{array}{l}\text { Used for the development of residential, commercial and } \\
\text { industrial areas and other construction land. }\end{array}$ & $\begin{array}{l}\text { A rectangular land area formed by criss-cross partition of roads and } \\
\text { has significant dense distribution of buildings. }\end{array}$ \\
\hline 09 & Road & Various types of railway, highway or rural roads for traffic. & $\begin{array}{l}\text { A grid-like or striped gray brown or light gray area that connects } \\
\text { each building land, fishing pond area and salt pool area. }\end{array}$ \\
\hline 10 & Farmland & Various types of arable land and grounds for farming. & $\begin{array}{l}\text { An area with cultivated land patches or planting facility patches } \\
\text { under mosaic distributions. }\end{array}$ \\
\hline
\end{tabular}




\section{Rectification and interpretation of remote sensing images}

25 ground control points are evenly laid and surveyed in study areas, and rectification of satellite remote sensing images is carried out by using ERDAS IMAGE9.2, refer to the rectification method in relevant literature (Wu et al., 2011; Moffett et al., 2015). Rectification effect of the rectified images is checked by comparison between the rectified GF-1 satellite remote sensing images and Spot-5 satellite remote sensing images. Landscape types in the study areas are divided into 10 types including salt pool, fishing pond, wetland, water intake and outlet, lake, cofferdam dam, building land, road, farmland, grassland according to water landscape pattern characteristics in study areas and are based on site survey, and a remote sensing image feature library is set up for each kind of landscape type, refer to the description of each landscape type in Table 2. Based on the remote sensing image feature library and supported by ARCGIS10.0 software, a man-machine interactive interpretation is carried out for the Spot-5 satellite remote sensing images collected in 2005 and GF-1 remote sensing images collected in 2015 first (Suo et al., 2015), landscape pattern vector data of study areas in 2005 and 2015 is gained via visual interpretation. Then overlay satellite remote sensing images of 1990 and 2000 based on the landscape pattern vector data of study areas in 2005, modify them to landscape pattern vector data of study areas in 1990 and 2000 via visual interpretation in accordance with remote sensing image data; overlay satellite remote sensing images of 2010 based on the landscape pattern vector data of study areas in 2015 , modify them to landscape pattern vector data of study areas in 2010 via visual interpretation in accordance with remote sensing image data. Precision evaluation on landscape patch type data is carried out by adopting on-site GPS verification points, and the overall interpretation precision of remote sensing images are calculated to be $95 \%, 96 \%, 99 \%, 98 \%$ and $100 \%$ in the year 1990, 2000, 2005, 2010 and 2015, respectively.

\section{Analysis method of landscape pattern changes}

Some landscape pattern indexes such as water landscape dominant index, wetland index and building disturb index that can reflect water landscape pattern characteristics in accordance with the water landscape pattern characteristics in study areas are created in this paper, and the calculation methods of each evaluation index are as follows:

\section{Water landscape dominant index}

Water landscape dominant index refers to the dominance of water landscape in regional landscape patterns. The dominant index in this paper mainly refers to that of salt pools, fishing ponds, water intakes and outlets as well as lakes in regional landscape patterns, which adopts water landscape dominant index to describe the dominance of water landscape; the calculation of water landscape dominant index is as follows: 


$$
D_{w}=\frac{\sum_{j=1}^{4} \sum_{i=1}^{n} a_{i}}{A}
$$

Where, $\mathrm{D}_{\mathrm{w}}$ refers to water landscape dominant index, A refers to the total area of landscape patterns in the study area, ${ }^{a_{i}}$ refers to area of $\mathrm{i}$ water landscape patch, $\mathrm{i}$ refers to the number of patches, $\mathrm{j}$ refers to the number of water landscape types.

\section{Wetland index}

The study areas in this paper were originally muddy wetlands, however the muddy wetland landscape has been rarely preserved except for some landscapes remained in tidal creeks and ponds in low-lying areas due to the massive human exploitation and cofferdam. In order to reflect the degree of wetland retention and restoration in study area, this paper adopts wetland index to describe the degree of wetland retention and restoration; the calculation is as follows:

$$
W=\frac{\sum_{i=1}^{n} b_{i}}{A}
$$

Where, W refers to wetland index, A refers to the total area of landscape patterns in

study area, $b_{i}$ refers to area of $i$ wetland patch, $i$ refers to the number of wetland patches.

\section{Building disturb index}

The water landscape pattern changes in study areas are mainly driven by human construction disturbance, which mainly consists of industry-town building land expansion and road expansion. In order to reflect the spatial and temporal differences of human construction on disturbance of water landscape patterns, this paper adopts building disturb index to describe the disturbance of human construction on water landscape patterns; the calculation is as follows:

$$
G=\frac{\sum_{j=1}^{2} \sum_{i=1}^{n} g_{i}}{A}
$$


Where, $\mathrm{G}$ refers to building disturb index, A refers to the total area of landscape patterns in study area, ${ }^{g}$ refers to area of $\mathrm{i}$ building disturb patch, $\mathrm{i}$ refers to the number of building disturb patches, $\mathrm{j}$ refers to the number of building disturb landscape types.

\section{Landscape pattern stability}

In recent years, China's coastal water landscape patterns are under strong disturbance of human activities, and most of the landscape patterns are changing rapidly with high unstabitily (Serif et al., 2013). In order to reflect the unstabitily of landscape patterns caused by mutual transition of different types of landscape patches, this paper constructs the following analysis method of landscape pattern stability: If within the five periods of this study, the type of a landscape patch remains the same in whole or in part at every time point after the starting point, that is to say type transition never happened, then the stability is the highest which is I degree; if a landscape patch changes to another type in whole or in part that is different from the type at the previous time point at every time point after the starting point, that is to say type transition happened 4 times, then the stability is the lowest which is V degree; And so forth, if the type of a landscape patch is different from the type at the previous time point in whole or in part for 1 time within the 4 time points after the starting point, then stability level is II degree, if the type is different from the type at the previous time point for 2 times, then stability level is III degree, and IV degree if it is different for 3 times. In specific operation, GIS Overlay function is mainly used to convert the vector data of landscape patterns in 5 periods into raster format for overlay operations after marking, and the number of grids that occurred different landscape type changes is counted through analysis of the transition of grid landscape type by each grid value.

\section{Result analysis}

\section{Overall change of coastal water landscape patterns}

The change of coastal water landscape patterns in study areas is mainly represented by the change of different landscape type area. Landscape pattern composition in 5 periods in study areas (Table 3) is gained according to the vector data of landscape patterns in 5 periods in study areas.

Table 3. Landscape pattern composition in 5 periods in study areas

\begin{tabular}{llllll}
\hline Landscape & $\mathbf{1 9 9 0}$ & $\mathbf{2 0 0 0}$ & $\mathbf{2 0 0 5}$ & $\mathbf{2 0 1 0}$ & $\mathbf{2 0 1 5}$ \\
type & Ratio $(\boldsymbol{\%})$ & Ratio $(\boldsymbol{\%})$ & Ratio $(\boldsymbol{\%})$ & Ratio $(\boldsymbol{\%})$ & Ratio $(\boldsymbol{\%})$ \\
\hline Salt pool & 67.87 & 65.80 & 62.91 & 38.02 & 25.62 \\
Fishing pond & 9.65 & 13.81 & 15.44 & 18.78 & 20.78
\end{tabular}




\begin{tabular}{llllll}
$\begin{array}{l}\text { Water intake } \\
\text { and outlet }\end{array}$ & 3.58 & 3.06 & 3.84 & 3.11 & 2.98 \\
$\begin{array}{l}\text { Cofferdam } \\
\text { dam }\end{array}$ & 5.65 & 6.54 & 5.54 & 2.96 & 1.49 \\
Wetland & 2.38 & 1.12 & 1.12 & 10.12 & 4.25 \\
Lakes & 0.05 & 0.05 & 0.04 & 0.85 & 0.80 \\
Grassland & 0.32 & 0.67 & 2.26 & 8.43 & 23.01 \\
Building land & 5.63 & 6.02 & 6.77 & 12.99 & 16.34 \\
Road & 1.02 & 0.86 & 0.76 & 3.74 & 4.32 \\
Farmland & 3.87 & 2.07 & 1.32 & 1.00 & 0.42 \\
\hline Total area & 27574.24 & 27751.22 & 27940.59 & 29472.66 & 30242.93 \\
$\left(\mathrm{hm}^{2}\right)$ & & & & \\
\hline
\end{tabular}

Salt pools and fishing ponds are the most important landscape types in south Yingkou coastal water landscape, wherein salt pools have always been the main body of the regional coastal water landscape patterns. Viewing from the changes in 1990-2015, salt pool area continued to decrease, with a decreasing rate reaching $42.25 \%$. In 1990, salt pool area had reached $18,714.24 \mathrm{hm}^{2}$, accounting for $67.87 \%$ of the total regional area, later, with the expansion and renovation of aquatic fishing ponds, the area ratio decreased to $65.80 \%$ in 2000 , and further reduced to $62.91 \%$ in 2005 . After 2008, with the increasing strength of the Liaoning coastal development, a large area of salt pools are filled for industry and town building land or adapted to aquatic fishing ponds, the proportion of salt pool area significantly reduced to $38.02 \%$ in 2010 , and further reduced to $25.62 \%$ in 2015 , a significant decline in the dominant position. The fishing pond area was $2,662.04 \mathrm{hm}^{2}$ in 1990 , which is the second largest water landscape type following salt pools within the region, with an area ratio of $9.65 \%$. Thereafter the area continued to expand, reaching $13.81 \%$ in $2000,15.44 \%$ in $2005,18.87 \%$ in 2010 , and further increased to $25.62 \%$ in 2015. Building land and grassland are the two most significant non-water landscape types in area increase, where building land area was only $1,551.21 \mathrm{hm}^{2}$ in 1990 , accounting for $5.63 \%$ of the total regional area, later, driven by the continuous expansion of urban and industrial construction, the area accounted for $6.02 \%$ in $2000,6.77 \%$ in 2005 , substantially increased to $12.99 \%$ in 2010 , and further reached $16.34 \%$ in 2015 . Grassland is a natural landscape type generated by human activities in the region, which had only $88.24 \mathrm{hm}^{2}$ in 1990 , and it accounted for $2.26 \%$ of the total regional 1 area in 2005 , increased to $8.43 \%$ in 2010 , and substantially increased to $23.01 \%$ in 2015 , becoming the second largest landscape type following salt pool landscape in the region. The ratios of other landscape type areas within the study areas are relatively small, and the ratios of water intakes and outlets, cofferdam dam and farmland decreased from $3.58 \%, 5.65 \%$ and $3.78 \%$ in 1990 to $2.98 \%, 1.49 \%$ and $0.42 \%$ in 2015 , respectively; while the ratios of wetland and road area decreased from $2.38 \%$ and $1.02 \%$ in 1990 to $4.25 \%$ and $4.32 \%$ in 2015 , respectively. In addition, due to the 
continuous human activities in wetland of salt pools such as reclamation aquaculture, the total area of landscape patterns in the study areas continued to fluctuate, increased from $27574.24 \mathrm{hm}^{2}$ in 1990 to $30242.93 \mathrm{hm}^{2}$ in 2015 , a net increase of $2,668.69 \mathrm{hm}^{2}$ in 25 years.

\section{Spatio-temporal dynamics characteristics of coastal water landscape patterns}

Water landscape dominant index of the study area was generally high in 1990, even the lowest water landscape dominant index of north sub-region reached 0.65 , south sub-region reached 0.95 , overall regional water landscape dominant index was 0.81 , indicating that salt pools, fishing ponds and other water landscapes occupy a high proportion in the entire study area at the time and water landscape pattern characteristics were very obvious which lasted until 2005 (Figure 2). In 2010, water landscape dominant index of north sub-region dropped sharply to 0.18 , water landscape dominant index of middle sub-region has also reduced to 0.75 , water landscape dominant index of south sub-region does not change a lot, overall regional water landscape dominant index was 0.61 , indicating that salt pool water landscape in north sub-region went through large-area land reclamation and transformation in 2005-2010. In 2015, water landscape dominant index of middle sub-region dropped sharply to 0.56 , the north sub-region and south sub-region also reduced to 0.15 and 0.85 , respectively, overall regional water landscape dominant index was 0.50, indicating that reclamation and transformation of salt pool water landscape mainly occurred in middle sub-region and north sub-region, and the reclamation and transformation area of salt pool water landscape in south sub-region occupies a smaller proportion in 2010-2015.

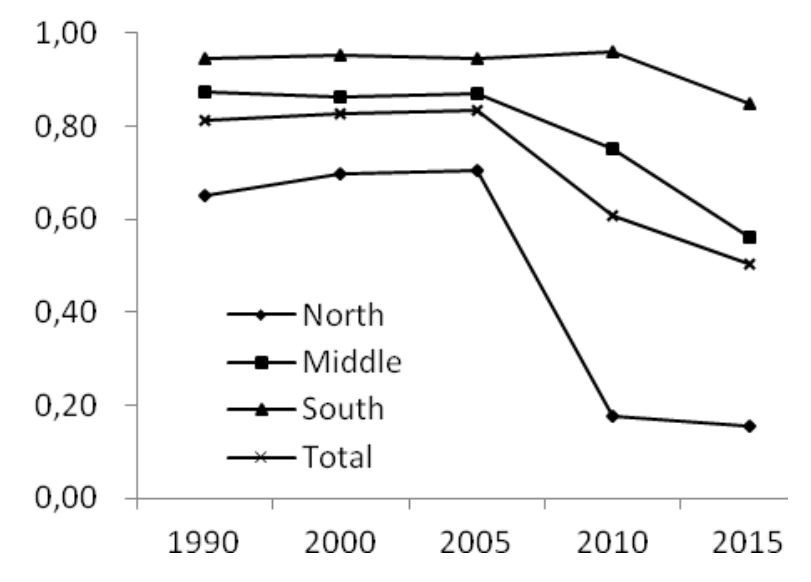

Figure 2. Change of water landscape dominant index

As can be seen from Figure 3 change of wetland index, the wetland index of north sub-region was 6.16 in 1990, indexes in middle sub-region and south sub-region are all less than 0.50 , indicating that the only small amount of wetland was mainly distributed in the north sub-region, wetland in the middle sub-region and south sub-region 
cofferdam range was almost all exploited at that time. In 2000 and 2005, wetland index of the north sub-region decreased to 2.95 and 3.41, wetland index of middle sub-region and south sub-region changed little, indicating that the development intensity of the wetland in north sub-region further increased during this time, and a small amount of residual wetland was also exploited. In 2010, wetland index of the north sub-region and middle sub-region sharply increased, reaching 16.13 and 11.50, respectively, south sub-region changed little, overall regional wetland index reached 10.12, indicating that there were a lot of salt pools in the north sub-region and middle sub-region converted into wetland after being discarded in 2005-2010. In 2015, wetland index of the north sub-region and the middle sub-region decreased to 4.65 and 2.77 , respectively, while the wetland index of south sub-region rose to 5.73, indicating that part of the previous salt pools in the north sub-region and middle sub-region are converted into other landscape types after being discarded and converted into wetland, while the south sub-region appeared a certain proportion of waste salt pools being converted to wetland in 2010-2015.

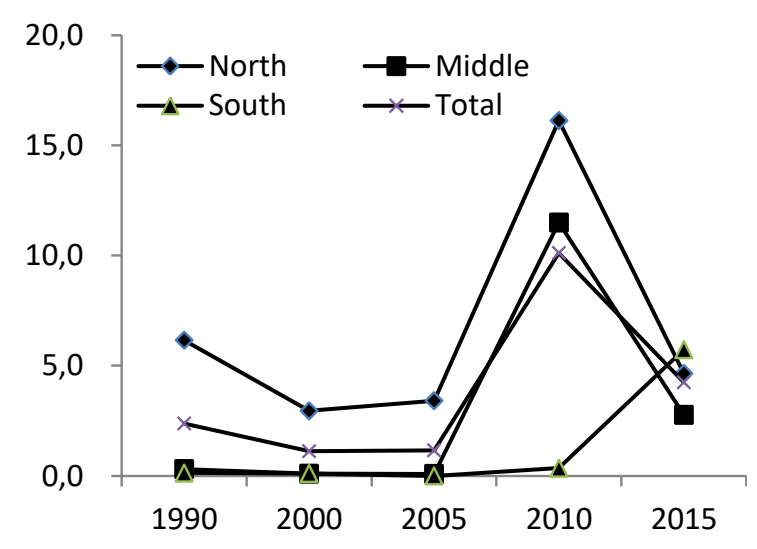

Figure 3. Change of wetland index

As can be seen from Figure 4 change of building disturb index, building disturb index of study area was generally low in 1990, the highest in the north sub-region was only 14.80, indexes in middle sub-region and south sub-region were only 2.80 and 1.00 , respectively, indicating that industry and town building land and roads occupy a low proportion in water landscape patterns at the time, and human construction has a very low disturbance on water landscape patterns. In 2010, building disturb index of the north sub-region and middle sub-region significantly increased, reaching 39.00 and 7.40, respectively, while the south sub-region remained at 1.20, indicating that the disturbance of industry and town building land expansion and road expansion in the north sub-region and middle sub-region during 2005-2010 on water landscape patterns increased significantly, while the human construction disturbance received by water landscape patterns in south sub-region is still small. In 2015, building disturb index of the north sub-region further increased to 45.40, middle sub-region and south sub-region also 
increased to 10.30 and 4.40, respectively, overall regional building disturb index was 20.70 , indicating that building disturb index of industry and town and road in the north sub-region has already been large, building land, roads and other non-water landscape types have become the main body of regional landscape patterns, water landscape patterns have thoroughly changed, the disturb index of industry and town road construction in middle sub-region and south sub-region is also gradually increasing, and disturb index of water landscape pattern is growing.

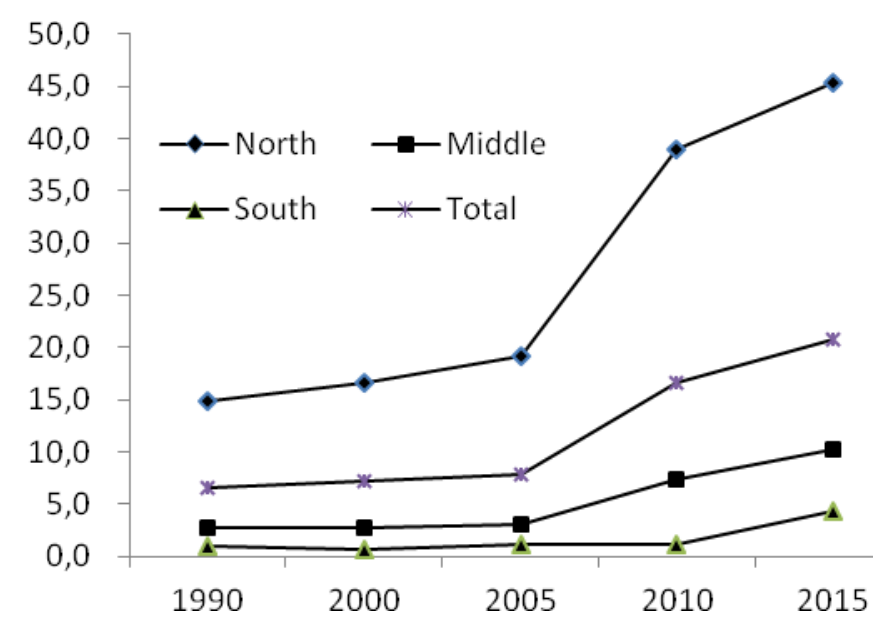

Figure 4. Change of building disturb index

\section{Stability of coastal landscape}

As can be seen from Figure 5 landscape pattern stability degree in study areas and its statistics, I degree area with the highest landscape stability covers $9,242.37 \mathrm{hm}^{2}$, accounting for $35.73 \%$ of the total area, of which the north sub-region covers $1,705.36 \mathrm{hm}^{2}$, mainly distributed in the most northern part and local area of the southeast corner of Yingkou city; middle sub-region covers $3,810.02 \mathrm{hm}^{2}$, mainly distributed in middle of the region; south sub-region covers $3,726.99 \mathrm{hm}^{2}$, mainly distributed in middle of the east coastal zone and the northeast. II degree area with the second highest landscape stability covers $10,311.86 \mathrm{hm}^{2}$, accounting for $39.86 \%$ of the total area, also the highest landscape degree in the region. Seen from regional distribution, the north sub-region covers $3,512.14 \mathrm{hm}^{2}$, mainly distributed in the original salt pool area in the southwest; middle sub-region covers $4,511.04 \mathrm{hm}^{2}$, mainly adjoining the west original salt pool area and northeast salt pools of the coastal zone; south sub-region covers $2,288.68 \mathrm{hm}^{2}$, mainly distributed in the middle original salt pool area. III degree landscape stability area covers $3,934.50 \mathrm{hm}^{2}$, accounting for $15.21 \%$ of the total area, mainly distributed in the north sub-region, covering $2,999.52 \mathrm{hm}^{2}$. V degree area with the lowest landscape stability covers the smallest area which is $1,042.98 \mathrm{hm}^{2}$, accounting for $4.03 \%$ of the total area, mainly distributed in the peripheral I degree north sub-region, and local areas of middle sub-region and south sub-region, which cover a small area. In addition, 
IV degree area with the second lowest landscape stability covers $1,338.58 \mathrm{hm}^{2}$, accounting for $5.17 \%$ of the total area, mainly distributed in local north sub-region, and rarely in middle sub-region and south sub-region.

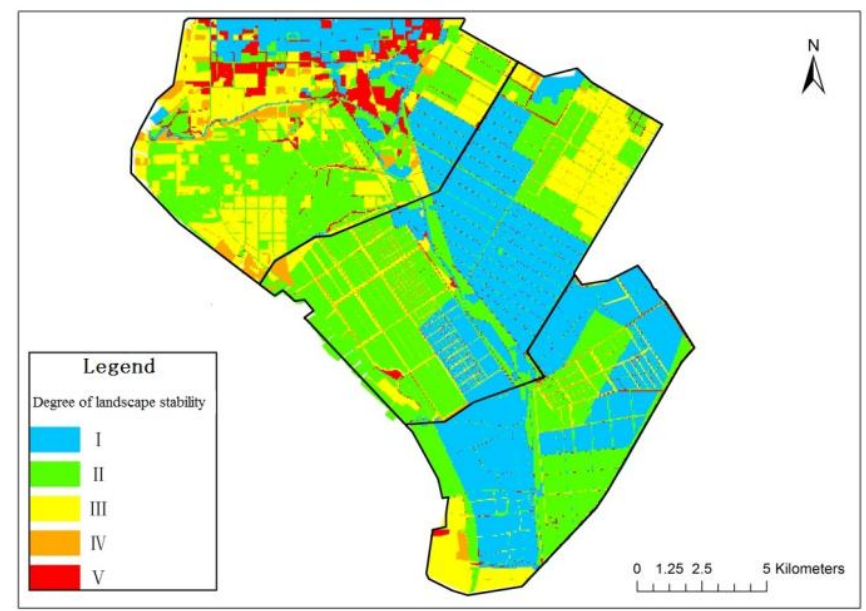

Figure 5. Degree of Landscape stability in study areas

\section{Discussion}

In recent years, large-scale sea reclamation is the most important driving force of coastal landscape pattern change in China. The coastal landscape patterns of many regions have occurred significant change on driving of large-scale sea reclamation activities (Guan, 2012; Yu and Suo, 2013; Cengiz, 2014). The south Yingkou coastal zone is one of most typical region, its coastal landscape pattern have changed rapidly drove by large-scale sea reclamation human activities since 1990. However, some difference appeared in the different sub-regions.

The north sub-region is close to Yingkou city, except the north part remains stable, other parts all occurred large changes, the change of landscape patterns as follow: salt pools are divided into fishing ponds, fishing ponds are discarded to be wetland due to low efficiency, wetland is constructed into building land such as industrial zone and towns in the form of sea reclamation after carried of Liaoning coastal economic zone. In 2015, building land in the north sub-region accounted for $37.50 \%$ of the total area, and the building land become the most important landscape type. The north sub-region is the most complex landscape stability, urban building land and part of the salt pools maintained the original type, with the highest landscape stability; large areas of salt pools are deserted into grassland after reclamation due to the lack of no settlement. The landscape type which changed 1 time, is the second highest landscape stability, accounting for $36.05 \%$ north sub-region area; Areas with III degree landscape stability that occurred 2 times landscape type change mainly include salt pools at southwest that converted into fishing ponds or deserted to be wetland firstly, the fishing ponds or wetland is reclaimed to building land for industry and town; or salt pools is reclaimed and deserted to grassland firstly, and the grassland is developed to industrial building land. 
Areas with IV degree and V degree landscape stability that occurred above 3 times of landscape type change mainly include salt pools that converted into fishing ponds, fishing ponds deserted to wetland, wetlands reclaimed to industrial zones and town building land, or salt pools was deserted to wetland, wetland was filled and changed to grassland, the grassland was developed for industrial land. Or caused by frequent changes in water intake and drainage tidal creeks.

The landscape pattern changed in middle sub-region as follows: salt pools were reclaimed to land, a part of the land was converted to building land for industry and town due to settlement of projects, most of the land was converted to grassland due to absence of projects and construction. In 2015, the area of grassland in middle sub-region reached $3,195.77 \mathrm{hm}^{2}$, accounted for $28.24 \%$ area of the whole region, becoming the second largest landscape type following salt pools. For the time being, the dominant index of salt pools, fishing ponds and other water landscapes was 0.56 , however, building disturb index of industry and town as well as roads was only 10.30, indicating that the current middle sub-region has converted into a land and water landscape structure that lays equal stress on salt pools, fishing ponds and other water landscapes as well as grassland, building land and other terrain landscapes. Landscape stability degree in middle sub-region concentrates mainly onI degree, II degree and III degree, I degree area refers to salt pool areas that have not been converted, II degree area refers to grassland areas that reclaimed from salt pools, III degree area refers to areas that deserted into wetland from salt pools and then reclaimed to industrial building land.

There are only a part of salt pools in south sub-region was converted to building land and grassland, most of the region still remains salt pools, fishing ponds and other water landscapes, the dominant index of water landscape reaches up to 0.85 , however building disturb index is only 4.40, since a part of salt pools deserted and converted to wetland, wetland index rises to 5.73. In general, the current south sub-region still appears water landscape pattern which is dominated by salt pools and fishing ponds. Landscape stability degrees of south sub-region are mainly I degree, II degree and III degree, I degree area refers to areas that remained salt pools, II degree refers to grassland landscape areas which converted from fishing ponds and salt pools, III degree area refers to grassland landscape areas which converted from fishing ponds and salt pools, then fishing ponds were reclaimed and deserted.

\section{Conclusion}

This paper analyzed the coastal landscape pattern change process from salt pool to industry and town in south Yingkou coast, China in 1990-2015. Satellite remote sensing images with high spatial resolution were employed as basic data. The constructing dominant index, wetland index and building disturb index that can reflect coastal landscape pattern, as well as landscape stability analysis method were created as methods. The results show: salt pools, fishing ponds and other water landscape in south Yingkou coast continued to decrease, the area of salt pools reduced from $18,714.24 \mathrm{hm}^{2}$ to $7,748.94 \mathrm{hm}^{2}$, however building land and grassland rapidly increased, accounting for 
$21.21 \%$ and $23.01 \%$ of the total regional landscape pattern area, respectively, characteristics of coastal water landscape gradually reduced. On driving of large-scale human activities, coastal landscape pattern change appears evident regional difference. The north sub-region has converted to industry \& town terrain landscape from salt pools, fishing ponds and other water landscape, dominant index of water landscape reduced from 0.65 to 0.15 , while building disturb index increased from 14.80 to 45.40 . Tthe middle sub-region is in the converting process from salt pools, fishing ponds and other water landscape to grassland, building land and other terrain landscape, dominant index of water landscape reduced from 0.88 to 0.56 , building disturb index increased from 2.80 to 10.30 . The south sub-region still maintains the dominance of salt pools, fishing ponds and other water landscape, dominant index of water landscape remained at 0.85 despite the slight decrease, building disturb index was 4.40 . The landscape stability degree of Iand II covered most areas. I degree area accounting for 35.73\% and II degree area accounting for $39.86 \%$ of the total area, areas occurred landscape type change for more than 2 times accounted for $24.41 \%$ of the total area.

Acknowledgements. This paper is funded by National Natural Science Funds of China (No.41376120) and the Chinese Special Project for Marine Public (No.201105006), the views expressed are authors' alone.

\section{REFERENCES}

[1] Carter, R. W. G. (1988): Coastal Environment. -Academic Press, Tokyo.

[2] Cengiz, T.(2014): Visual quality method in assessing landscape characteristics: case study of Bozcaada island. -Journal of Coastal Research 30(2):319-327.

[3] Chen, L. D., Fu, B. J.(1996): Analysis of impact of human activity on landscape structure in Yellow river delta: a case study of Dongying region. -Acta Ecologica Sinica 16(4):337-344.

[4] Forman, R. T. T., Godron, M. (1986): Landscape Ecology. -John Wiley\&Son, New York.

[5] Gao, Z. Q., Liu, X. Y., Ning, J. C., et al. (2014): Change of coastline and sea areas reclamation in China in last 30years based on remote sensing. -Transactions of the Chinese Society of Agricultural Engineering 30(12):140-147.

[6] Gaun, D. M. (2012): Coastal wetland in China. -Marine Press, Beijing.

[7] Liu, C. Y., Zhang, S. Q., Jiang, H. X. (2009): Spatiotemporal dynamics and landscape pattern of alien species Spartina alterniflorn in Yancheng coastal wetlands of Jiangsu province, China. -Chinese Journal of Applied Ecology 20(4):901-908.

[8] Moffett, K. B., Nardin, W., Silvestri, S., et al. (2015): Multiple stable states and catastrophic shifts in coastal wetlands: progress, challenges, and opportunities in validating theory using remote sensing and other methods. -Remote Sens 7:10184-226.

[9] Serif, H., Cigdem, C. H., Cigdem, K., et al. (2013): Analyzing landscape change and urban sprawl in a Mediterranean coastal landscape: A case study from Izmir, Turkey. -Journal of Coastal Research 29(2):301-310. 
[10] Sun, Y. G., Li, X. Z., Guo, W. Y., et al.(2011): Contribution rates of landscape driving factors in coastal reclamation zone based on CLUE-S model validation. -Chinese Journal of Applied Ecology 22(9):2391-2398.

[11] Sun, Y. G., Li, X. Z., He, Y. L., et al.(2010): Spatiotemporal dynamics of land use and land cover changes in different reclamation zones of Yangtze Estuary. -Chinese Journal of Applied Ecology 21(2):434-441.

[12] Sunamura, T.(1992): Geomorphology of rocky coasts. -Wilet, Chichester.

[13] Suo, A. N., Sun, Y. G., Li, B. Y.(2015): Vegetation landscape health assessment in Changshan islands. -Chinese Journal of Applied Ecology 26(4):1034-1040.

[14] Suo, A. N., Zhang, M. H.(2015): Sea areas reclamation and coastline change monitoring by remote sensing in coastal zone of Liaoning in China. -Journal of coastal research 73(SI):725-729.

[15] Suo, A. N., Zhao, D. Z., Ge, J. P. (2009): Application of landscape ecology in offshore resources and environment: discussion of marine landscape ecology development. -Acta Ecologica Sinica 29(9):5098-5105.

[16] Wan, J., Li, Z. C., Lei, K.(2009): Dynamics analysis of coastal landscape pattern in typical region of Bohai bay from 1954-2000. -Research of Environment Science 22(1):162-168.

[17] Wang, X. L., Xiao, D. N., Bu, R. C., et al.(1997): Analysis of landscape pattern in Liaohe delta. -Acta Ecologica Sinica 17(5):317-323.

[18] Wu, T., Zhao, D. Z., Zhang, F. S., et al.(2011): Change of wetland landscape pattern in Dayanghe River estuary based on high-resolution remote sensing image. -Chinese Journal of Applied Ecology 22(7):1833-1840.

[19] Xiao, D. N., Li, X. Z., Gao, J.(2003): Landscape ecology. -Science Press, Beijing.

[20] Xu, L. H., Li, J. L., Li, W. F., et al.(2014): Progress of influence of human activity on coastal resources and environment. -Journal of Nanjing Normal University(Natural edition) 37(3):124-131.

[21] Yang, S. L.(2003): Introduction of the coastal environment and the process of geomorphology. -Marine Press, Beijing.

[22] Ye, S. F., Ding, D. W., Wang, W. H.(2005): Large-scale estuarine engineering and estuarine habitat fragmentation of water body in the Yangtze River Estuary. -Acta Ecologica Sinica 25(2):268-272.

[23] Yu, Y. H., Suo, A. N.(2013): Methods research of reclamation assessment. -Marine Press, Beijing..

[24] Zeng, H., Zhao, N., Guo, Q. H.(1999): A study of landscape heterogeneity for the Changping area in the eastern part of Zhujiang delta. -Acta Geographica Sinica 21(3): $1542-1550$

[25] Zuo, P., Li, Y., Zhao, S. H.(2012): Landscape changes of Jiangsu Yancheng coastal wetlands and their driving forces since 1976. -Acta Oceanologica Sinica 34(1):101-108. 